\title{
ТОПЛИВНАЯ И НЕФТЕХИМИЧЕСКАЯ ПРОМЫШЛЕННОСТЬ РЕСПУБЛИКИ БЕЛАРУСЬ: ТЕНДЕНЦИИ И ПЕРСПЕКТИВЫ РАЗВИТИЯ
}

\author{
П.Е. РЕЗКИН \\ аспирант, ассистент кафедры экономики, управления и экономической теории \\ Полоцкий государственный университет, г. Новополоцк \\ Н.А. ХАУСТОВИЧ \\ к.э.н., доцент кафедры экономики и управления \\ Белорусский государственный экономический университет, г. Минск
}

\begin{abstract}
Аннотация
В статье проанализированы основные тенденции и выявлены перспективы развития топливной $и$ нефтехимической промышленности Республики Беларусь. Данные отрасли экономики технологически связаны и формируют основу топливно-энергетического комплекса республики. На основе авторской методики рассчитана величина чистого экспорта продукции нефтехимической промылиенности, с учетом использования импортных ресурсов в качестве промежуточного потребления. Выявлены существенные взаимосвязи нефтехимии с другими отраслями национальной экономики. Расчеты базируются на данных системы межотраслевых таблии «Затраты Выпуск» Республики Беларусь за 2012 год.
\end{abstract}

Annotation

The article analyzes the main trends and prospects of development identified fuel and petrochemical industry of the Republic of Belarus. These industries technologically connected and form the basis of the fuel and energy complex of the republic. On the basis of the author's methodology to calculate the value of net exports of petrochemical products, with the use of imported resources as an intermediate consumption. A significant relationship with other petrochemical industries of the national economy. Calculations based on the data of the interbranch table "Input - Output" of the Republic of Belarus for 2012.

\section{ВВЕДЕНИЕ}

В современных условиях хозяйствования все большую актуальность в развитии национальной экономической системы приобретают такие приоритетные направления, как энергоэффективность, ресурсосбережение, экспорториентированность и импортозамещение. Именно эти ориентиры являются основой нынешней государственной экономической политики Республики Беларусь. Данные вопросы является одними из часто обсуждаемых в научных кругах.

В тоже время развитие любой системы, в том числе экономической, зависит от ее качественного и количественного состава, т.е. ее составных элементов. Рассматривая экономическую систему, как экономику отдельно взятой страны, в качестве таких составных элементов могут выступать отдельно взятые субъекты хозяйствования, которые в совокупности представляют отрасли национальной экономики. Во многих странах одной из приоритетных и стратегически важных отраслей являются топливная и нефтехимическая промышленность, осуществляющие первичную переработку энергоресурсов с последующим производством топлива и синтетических материалов. С одной стороны эта отрасль является традиционной и относится к IV технологическому укладу, с другой стороны, в течение последних десятилетий инновации в данной отрасли существенно изменили технологии выпуска традиционных продуктов и привели к масштабным изменениям глобальных производственных цепочек. В качестве примеров можно привести производство биотоплива на основе растительного сырья; добычу сланцевой нефти и газа в США; использование синтетических материалов взамен металла в автомобильной и авиационной промышленности. Следовательно, несмотря на «традиционность» рассматриваемой отрасли, она является в высокой степени инновационной в передовых странах, что требует рассмотрения возможностей инноваций на белорусских предприятиях, топливной и нефтехимической промышленности.

В Республике Беларусь топливная и нефтехимическая промышленность представлена видами экономической деятельности «Производство кокса, нефтепродуктов и ядерных материалов», а также «Химическое производство», согласно классификатору ОКЭД.

В общем объеме отечественной промышленности продукты топливной и нефтехимической промышленности составляют около 30\%, а в общереспубликанском экспорте - около 50 \% [1]. Экспортный потенциал отрасли обеспечивают такие группы товаров, как сырая нефть и нефтепродукты, азотные и калийные удобрения, полиэтилен, химические волокна и нити, шины и др. Огромную роль играет нефтехимия в расширении сырьевой базы прочих отраслей промышленности, сельского хозяйства и строительства. Данная отрасли в общегосударственном масштабе обеспечивает существенную занятость населения - более 100 тыс. человек. В целом существующие инвестиционные проекты и государственные программы развития отрасли обеспечивают ее устойчивое развитие и высокую конкурентоспособность продукции. Однако дальнейшее развитие отрасли должно формироваться с учетом современных тенденций и перспектив развития, которые поможет выявить данная статья. 


\section{РЕЗУЛЬТАТЫ И ИХ ОБСУЖДЕНИЕ}

В целях изучения развития данной отрасли, а также выявления влияния топливной и нефтехимической промышленности на макроэкономическую динамику Республики Беларусь будем использовать таблицы межотраслевого баланса «Затраты-Выпуск» за 2012 год. Взятый временной промежуток объясняется значительной задержкой с предоставлением информации, что связано с высокой трудоемкостью ее обработки, а также с периодичностью расчета данных статистических таблиц.

Система таблиц «Затраты - Выпуск», являясь неотъемлемой частью СНС, содержит подробные характеристики производства и использования товаров и услуг, особенности формирования валовой добавленной стоимости, промежуточного и конечного спроса на уровне отраслевых группировок товаров и услуг и позволяет осуществить макроэкономический анализ этих показателей на более детальном уровне, дополняя и расширяя возможности СНС.

В состав системы таблиц «Затраты - Выпуск» Республики Беларусь входят такие таблицы как [2]:

- таблица ресурсов товаров и услуг;

- таблица использования товаров и услуг в ценах покупателей;

- таблица использования товаров и услуг в основных ценах;

- таблица использования отечественных товаров и услуг в основных ценах;

- таблица использования импортных товаров и услуг;

- таблица транспортных наценок;

- таблица торговых наценок;

- таблица чистых налогов на продукты;

- аналитические показатели таблиц ресурсов и использования товаров и услуг в ценах покупателей;

- таблица коэффициентов прямых и полных затрат.

Именно эти таблицы были использованы в качестве информационной базой для дальнейшего исследования. Общая схема основных таблиц представлена в таблицах 1,2 .

Таблица 1 - Схема таблицы «Ресурсы товаров и услуг»

\begin{tabular}{|l|c|l|c|c|c|c|c|}
\hline \multirow{2}{*}{ ВЭД } & $\begin{array}{c}\text { Валовой } \\
\text { выпуск } \\
\text { отраслей в } \\
\text { основных } \\
\text { ценах }\end{array}$ & Импорт & $\begin{array}{c}\text { Располагаемы } \\
\text { е ресурсы в } \\
\text { основных } \\
\text { ценах }\end{array}$ & $\begin{array}{c}\text { Чистые } \\
\text { налоги } \\
\text { на } \\
\text { продукты }\end{array}$ & $\begin{array}{c}\text { Рранспорт } \\
\text { ные }\end{array}$ & $\begin{array}{c}\text { торгово- } \\
\text { посреднич } \\
\text { еские }\end{array}$ & $\begin{array}{c}\text { Месурсе } \\
\text { ценах в } \\
\text { покупателя }\end{array}$ \\
\hline $\begin{array}{l}\text { Товары } \\
\text { и услуги }\end{array}$ & Ден. ед. & Ден. ед. & Ден. ед. & Ден. ед. & Ден. ед. & Ден. ед. & Ден. ед. \\
\hline Всего & Ден. ед. & Ден. ед. & Ден. ед. & Ден. ед. & Ден. ед. & Ден. ед. & Ден. ед. \\
\hline
\end{tabular}

Источник: составлено авторами на основе системы таблиц «Затраты-Выпуск»

С использование таблиц «Затраты - Выпуск» авторами будет проведен расчет величины экспорта в топливной и нефтехимической промышленности за счет импортных и местных ресурсов в сравнении с общереспубликанскими значениями. Для этих целей использована авторская методика, которая включает в себя 5 расчетных этапов.

Эman 1. Исходными данными для расчетов служит перечень показателей, информационной базой которых является система таблиц «Затраты - Выпуск»:

- валовая добавленная стоимость (ВДС),

- валовой выпуск товаров и услуг (В),

- промежуточное потребление (ПП),

- величина экспорта с наценками (налогами, транспортными и торговыми наценками) (ЭН),

- величина наценок (Н).

Таблица 2 - Схема таблицы «Ресурсы товаров и услуг»

\begin{tabular}{|l|c|c|c|c|c|}
\hline \multicolumn{1}{|c|}{ ВЭД } & $\begin{array}{c}\text { Промежуточный } \\
\text { спрос }\end{array}$ & $\begin{array}{c}\text { Конечное } \\
\text { потребление }\end{array}$ & $\begin{array}{c}\text { Валовое } \\
\text { накопление }\end{array}$ & Экспорт & $\begin{array}{c}\text { Всего использовано } \\
\text { ресурсов в ценах } \\
\text { покупателей }\end{array}$ \\
\hline $\begin{array}{l}\text { Промежуточное } \\
\text { потребление по } \\
\text { товарам и услугам }\end{array}$ & Ден. ед. & Ден. ед. & Ден. ед. & Ден. ед. & Ден. ед. \\
\cline { 1 - 2 } $\begin{array}{l}\text { Элементы } \\
\text { добавленной } \\
\text { стоимости }\end{array}$ & $\begin{array}{l}\text { В \% к общей } \\
\text { сумме ВДС }\end{array}$ & Ден. ед. \\
\cline { 1 - 2 } $\begin{array}{l}\text { Валовой выпуск } \\
\text { отраслей в } \\
\text { основных ценах }\end{array}$ & Ден. ед. & Ден. ед. & \\
\hline
\end{tabular}

Источник: составлено авторами на основе системы таблиц «Затраты-Выпуск» 
Эman 2. Расчет величины местного промежуточного потребления (МПП) ведется как произведение промежуточного потребления (ПП) и доли местных ресурсов (ДМР):

$$
\mathrm{M \Pi \Pi}=\Pi \Pi \times \text { ДMР },
$$

В свою очередь доля местных ресурсов (ДМР) определяется исходя из величины промежуточного потребления отечественных товаров (ППотеч):

$$
Д М Р=\frac{\Pi \Pi_{\text {OTEY }}}{\Pi \Pi}
$$

Этап 3. Определяется величина экспорта за счет местных ресурсов (ЭМР) как произведение доли местных ресурсов $\left(\mathrm{d}_{\mathrm{MP}}\right)$ а величину экспорта с наценками $\left(Э_{\mathrm{H}}\right)$ :

$$
\ni \mathrm{MP}=\mathbf{d}_{\mathrm{MP}} \times \ni_{\mathrm{H}}
$$

Доля местных ресурсов $\left(\mathrm{d}_{\mathrm{MP}}\right)$ в данном случае определяется как отношение местного промежуточного потребления (МПП) к валовому выпуску товаров и услуг (B):

$$
d_{M P}=\frac{M \Pi \Pi}{B},
$$

Эman 4. Расчет добавленной стоимости в экспорте (ДСЭ) ведется как произведение доли добавленной

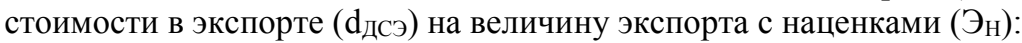

$$
\text { ДСЭ }=\mathbf{d}_{\text {дсэ }} \times \Im_{\mathbf{H}} \cdot
$$

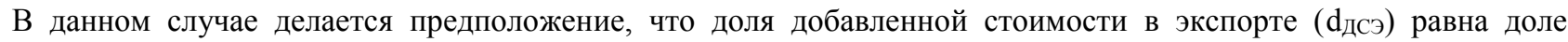
валовой добавленной стоимости (ВДС) в валовом выпуске товаров и услуг (В):

$$
d_{\text {дСэ }}=\frac{\text { ВДС }}{B},
$$

Эman 5. Расчет величины экспорта за счет импортных ресурсов (ЭИР) ведется как разница между величиной экспорта с наценками (ЭН), величиной экспорта за счет местных ресурсов (ЭМР), добавленной стоимости в экспорте (ДСЭ) и величины наценок (Н):

$$
\text { эИР }=\ni_{\mathbf{H}}-\text { ЭМР }- \text { ДСЭ }- \text { Н., }
$$

\section{ОПИСАНИЕ ОТРАСЛИ}

В Республике Беларусь топливная и нефтехимическая промышленность включает в себя три основных сегмента[3]:

1) нефтедобывающий сегмент со специализацией на добыче нефти и ее первичной подготовке;

2) нефтеперерабатывающий сегмент - основу топливной промышленности;

3) химическую отрасль.

В настоящее время предприятия топливной и нефтехимической промышленности объединяет концерн «Белнефтехим», на его долю приходится свыше 30 \% промышленного производства Республики Беларусь. В состав концерна входят более 60 организаций, среди которых ОАО «Нафтан» в Новополоцке, ОАО «Мозырский нефтеперерабатывающий завод», РУП «Производственное объединение «Белоруснефть», а также предприятия отрасли минеральных удобрений - ОАО «Беларуськалий», ОАО «Гродно Азот», ОАО «Гомельский химический завод» $[1,4]$.

Объемы нефтепереработки в Республике Беларусь на протяжении 2005 - 2013 гг. по данным Национального статистического комитета Республики Беларусь остаются стабильными на уровне около $21-22$ млн тонн в год, что является максимальным уровнем, начиная с 1991 года, за исключением некоторого снижения в 2010 году (до 16,5 млн тонн, что составляет снижение на 23,6 \% по сравнению с 2009 г.), в связи с сокращением поставок сырой нефти в Беларусь из Российской Федерации ввиду создания Единого Экономического Пространства (ЕЭП) и, как следствие, длительного согласования условий поставок нефти.

Соответственно данное событие оказало прямое влияние на снижение объемов производства нефтепродуктов в 2010 году (рис. 1). 


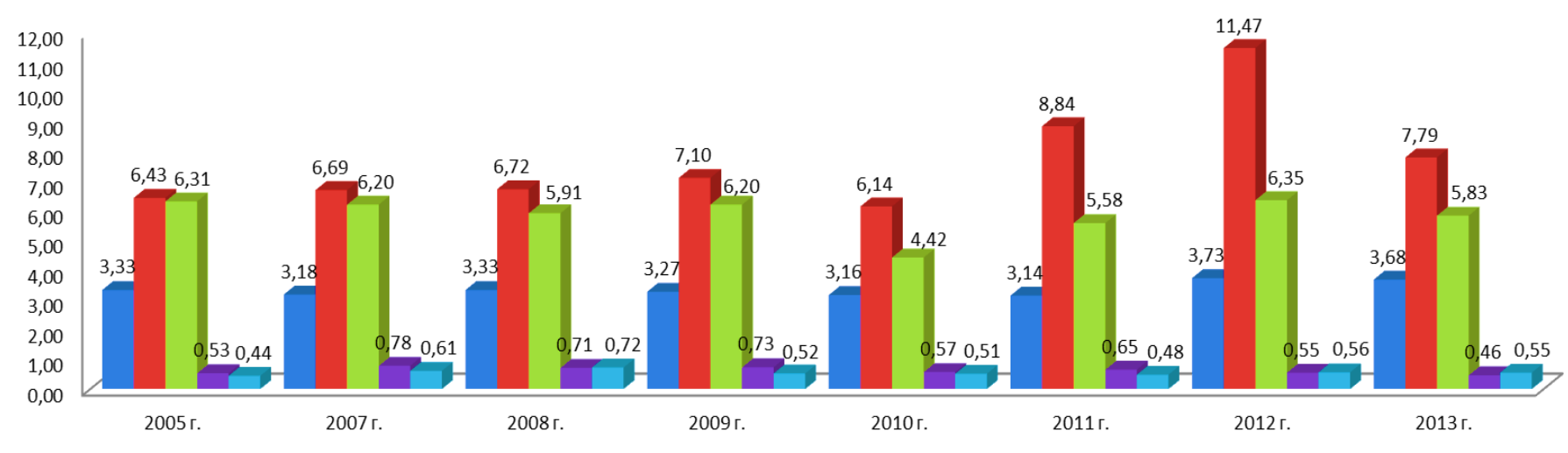

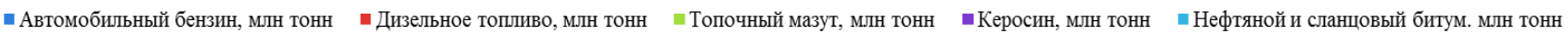
Рисунок 1 - Динамика объемов производства основных видов нефтепродуктов в Республике Беларусь за $2005-2013$ гг.

Источник: составлено авторами на основе данных Национального статистического комитет Республики Беларусь

В тоже время стоит отметить, что объемы производства бензинов уменьшились незначительно, что объясняется более эффективной переработкой нефти. Наибольший темп снижения наблюдался в производстве мазута (около $28,7 \%)$.

Данные явления не могли не сказаться на экономике Республики Беларусь в целом. Продукты нефтехимии (подсекция DF «Производство кокса, нефтепродуктов и ядерных материалов»; подсекция DG «Химическое производство») являются одной из основных статей экспорта Республики Беларусь. Экспорт нефтехимической промышленности составляет 39,42 \% от общего экспортного потока в 2012 году.

Рассматривая географическую направленность внешней торговли нефтехимической промышленности можно отметить, что основными рынками сбыта нефтепродуктов являются Украина (30,9 \% по данным за 2012 г.), Нидерланды (41,3\% по данным за 2012 г.) и Латвия (12,8 \% по данным за 2012 г.); сырой нефти - Германия (100 \% по данным за 2012 г.). Что касается импорта основными поставщиком как нефти, так и нефтепродуктов является Россия (96,2 \% по данным за 2012 г.).

Исходя из всего вышеперечисленного, необходимо отметить высокую зависимость внешней торговли нефтепродуктами Республики Беларусь от импортных поставок из Российской Федерации. В этой связи возрастает влияние экономической политики Российской Федерации на развитие нефтехимической отрасли Республики Беларусь.

Не смотря на высокую зависимость отрасли от Российской Федерации, в настоящее время продолжается реализация государственной комплексной Программы развития нефтехимического комплекса Республики Беларусь до 2015 года с перспективой до 2020 года, в соответствии с которой в топливной и нефтехимической промышленности было запланирована реализация более 40 крупных инвестиционных проектов.

Наряду с собственными средствами и кредитными ресурсами в качестве источников финансирования программы планировалось использование прямых иностранных инвестиций. В настоящее время переговоры по вопросам участия в развитии организаций концерна ведутся с рядом ведущих международных компаний.

В период 2011 - 2014 гг. в развитие нефтехимической промышленности направлено 58,3 трлн рублей инвестиций в основной капитал, завершено строительство 1459 объектов. В том числе в 2014 году в рамках реализации программ перспективного развития использовано 16,8 трлн рублей инвестиций в основной капитал.

С начала реализации данной Программы построены следующие стратегически важные для отрасли объекты, такие как [5]:

-установки гидроочистки дизельного топлива, изомеризации и вакуумной перегонки мазута в ОАО «Мозырский НПЗ»;

- установка низкотемпературной изомеризации, энерготехнологическая когенерационная установка, отделение компримирования в ОАО «Нафтан»;

- реконструкция ректификации цеха циклогексанон-2, установки совмещенного формования, технологическая установка по производству гранулята полиамида-6 в ОАО «Гродно Азот»;

- техническое перевооружение легкового потока и производства грузовых цельнометаллокордных шин, создание нового производства легковых шин с посадочным диаметром 15-18 дюймов в ОАО «Белшина»,

-производство мягкой полипропиленовой упаковочной тары и нетканых материалов, реконструкция производства полиэфирных текстильных нитей в ОАО «СветлогорскХимволокно».

Крупные проекты были также реализованы в РУП «ПО «Белоруснефть», ОАО «Гомельтранснефть Дружба», ОАО «Могилевхимволокно», ОАО «Полоцк-Стекловолокно» и на других предприятиях концерна.

В результате за период с 2011 по 2014 год концерном «Белнефтехим» обеспечен рост продукции промышленности более чем в 1,2 раза, экспорта товаров - в 1,47 раза (с 11 млрд долл. США в 2010 году до 16,2 млрд долл. США в 2014 году), положительного сальдо внешней торговли товарами - в 3,5 раза (с 1,87 млрд долл. США в 
2010 году до 6,5 млрд долл. США в 2014 году), что является значительным вкладом в сокращение отрицательного внешнеторгового сальдо страны.

Также стоит отметить, что незначительные последствия оказали кризисные явления в конце 2014 года на внешнюю торговлю в данной отрасли. При двукратном снижении котировок на нефть (с 106,8 в первом полугодии до 53,2 долл. США за баррель нефти сорта Urals на 31.12.2014 г.), темп роста экспорта товаров концерна снизился незначительно и составил 99,8 процента [6].

В 2015 году планируется завершить следующие важнейшие инвестиционные проекты [7]:

- «Реконструкция установки первичной переработки нефти АТ-8», «Строительство установки производства элементарной серы» в ОАО «Нафтан»;

- «Строительство комбинированной установки производства высокооктановых компонентов бензина», «Строительство установки производства серы (Сера-2)», «Строительство установки адсорбционной очистки бутановой фракции С4» в ОАО «Мозырский НПЗ»;

- «Освоение производства легковых шин с посадочным диаметром до 20 дюймов», «Техническое перевооружение завода крупногабаритных шин» в ОАО «Белшина»;

- «Комплексная реконструкция Белорусского газоперерабатывающего завода» на РУП «Производственное объединение «Белоруснефть»;

- «Строительство производства высокоочищенного парафина, масел, смазок, СОЖ, модельных составов с реконструкцией энергетического комплекса» в ОАО «Завод горного воска».

Особое внимание в 2015 и последующем годах концерном «Белнефтехим» будет уделено завершению модернизации нефтеперерабатывающих предприятий, действующих в рамках налогового маневра, введенного Российской Федерацией. Ускоренными темпами реализуются инвестиционные проекты, направленные на увеличение глубины переработки нефти и минимизацию выпуска темных нефтепродуктов.

Основными такими проектами являются:

- в ОАО «Нафтан» - комплекс замедленного коксования (срок реализации - декабрь 2016 г.);

- в ОАО «Мозырский НПЗ» - комплекс гидрокрекинга тяжелых нефтяных остатков (срок реализации декабрь 2017 года).

Стоимость проектов программ развития нефтеперерабатывающих предприятий составляет: ОАО «Нафтан»более 2 млрд долл. США; ОАО «Мозырский НПЗ» - почти 2,2 млрд долл. США [8].

Общую схему реализации Программы развития нефтехимического комплекса Республики Беларусь до 2015 года с перспективой до 2020 года можно видеть на рисунке 2.

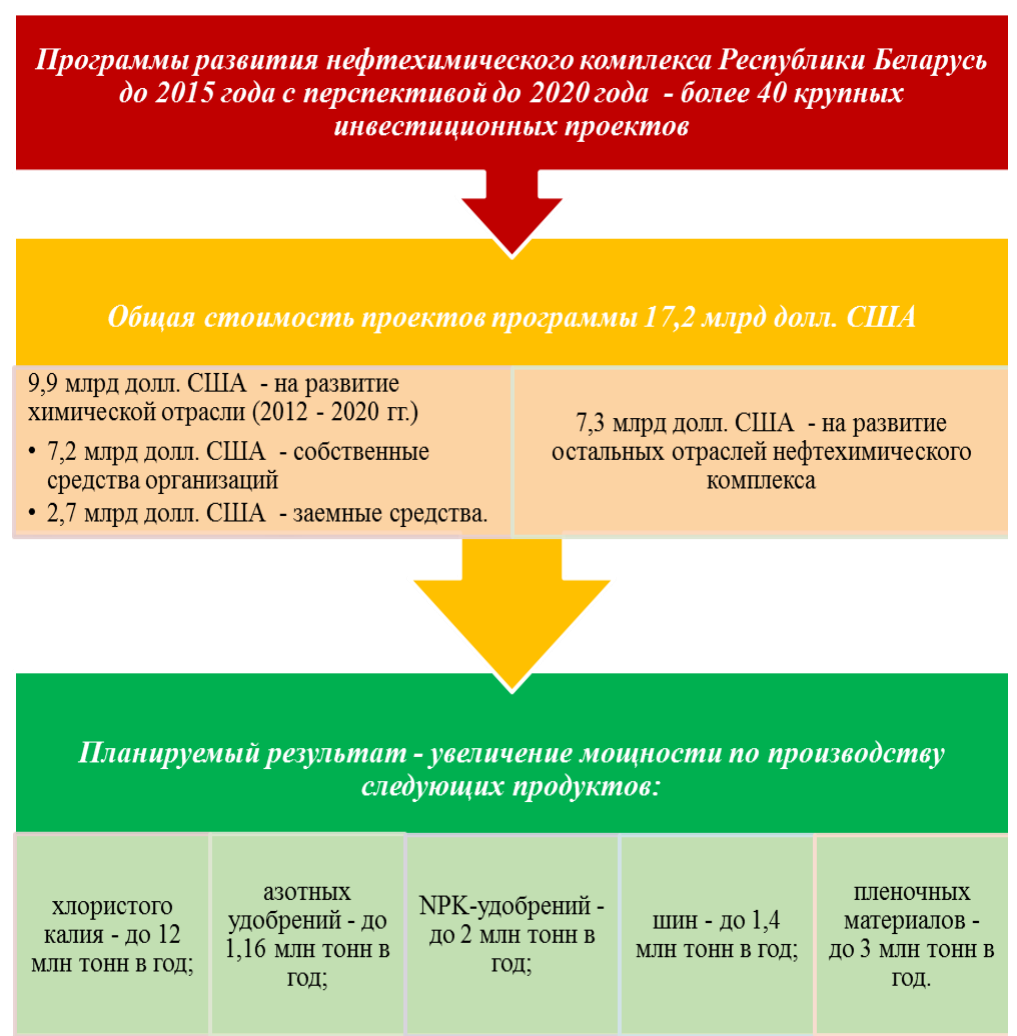

Рисунок 2 - Общая схема реализации Программы развития нефтехимического комплекса Республики Беларусь до 2015 года с перспективой до 2020 года

Источник: составлено авторами на основе данных концерна «Белнефтехим» 
Как отмечалось ранее, топливная и нефтехимическая промышленность включает в себя еще такой важный сегмент как производство химических волокон, нитей и полимеров, который базируется на продуктах нефтепереработки.

На долю Республики Беларусь приходится около половины общего объема производства химических волокон и нитей в СНГ. По отдельным видам продукции (полиэфирные волокна и нити, полиакрилонитрильные волокна, вискозная кордная ткань) Беларусь является монополистом на рынках СНГ.

Мощности всех предприятий химических волокон и нитей страны составляют порядка 310 тыс. тонн в год. В динамике производство химических волокон не является стабильным. Данные изменения в разрезе экспортной направленности можно видеть на рисунке 3.

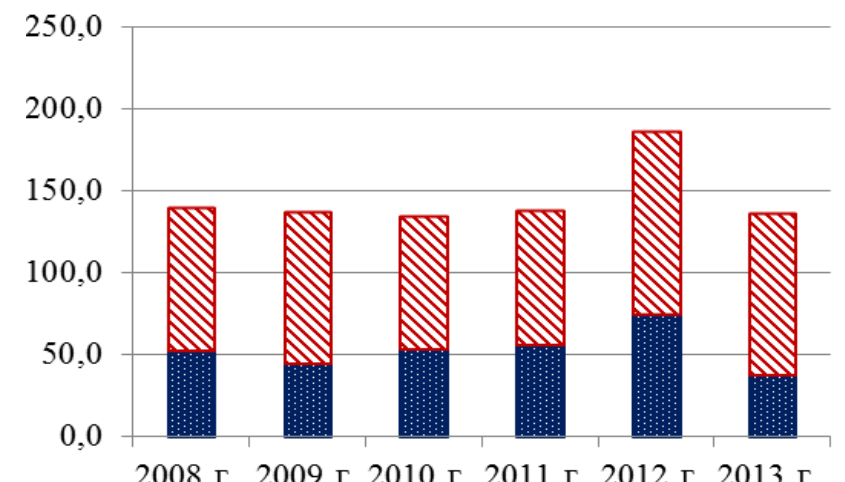

2008 г. 2009 г. 2010 г. 2011 г. 2012 г. 2013 г.

\Производство полиэтилена высокого давления

(ПЭВД) для экспорта, тыс. тонн

图 Производство полиэтилена высокого давления (ПЭВД)для внутреннего рынка, тыс. тонн

Рисунок 3 - Динамика производства ПЭВД и химических волокон и нитей в Республике Беларусь за 2008 - 2013 гг.

Источник: составлено авторами на основе данных Национального статистического комитет Республики Беларусь

Как видно из рисунка 3, экспорт химических волокон и нитей составляет около 70 \% внутреннего производства. В 2013 г. данный показатель составил 60,6\%.

Основной проблемой промышленности химических волокон Беларуси является глубокий износ основных производственных средств. Это относится ко всем предприятиям химических волокон страны и, в особенности, к вискозным производствам.

Также стоит отметить, что, не смотря на довольно развитую химическую промышленность, в Республике Беларусь производится только один вид полимера - полиэтилен высокого давления (ПЭВД). Собственное производство полиэтилена низкого давления (ПЭНД) и полипропилена отсутствует. Единственный производитель ПЭВД - ОАО «Нафтан» завод «Полимир», мощности которого позволяют выпускать до 140 тыс. тонн ПЭВД в год [9].

Рассматривая химическую промышленность, как часть нефтехимической отрасли, представим отраслевую структуру производителей с укрупненными наименованиями производимой продукции в виде таблицы 1.

Таблица 1 - Ключевые предприятия химической отрасли

\begin{tabular}{|c|l|}
\hline Основные производители отрасли & \multicolumn{1}{|c|}{ Производимая продукция } \\
\hline ОАО «СветлогорскХимволокно» & $\begin{array}{l}\text { Полиэфирные нити, вискозный корд, углеродные материалы, арселон, } \\
\text { нетканые материалы. }\end{array}$ \\
\hline ОАО «МогилевХимволокно» & $\begin{array}{l}\text { Полиэтилентерефталат, волокно и жгут полиэфирные, нити полиэфирные, } \\
\text { наполнитель полиэфирный, полиэфирные композиционные материалы, } \\
\text { полиэфирные термоэластопласты, полотна полиэфирные. }\end{array}$ \\
\hline ПТК «Химволокно» & $\begin{array}{l}\text { нить полиамидная, нить полиэфирная, кордная ткань для шинной } \\
\text { промышленности, нить полиамидная текстурированная ВСF; } \\
\text { Полиамид-6, полимерные композиционные материалы на основе ПА-6. }\end{array}$ \\
\hline Завод «Полимир» ОАО «Нафтан» & $\begin{array}{l}\text { Акриловые волокна: НИТРОН-С и НИТРОН-Д (жгут и волокно для } \\
\text { текстильной, трикотажной и ковровой промышленности), ПЭВД. }\end{array}$ \\
\hline
\end{tabular}

Источник: составлено авторами на основе данных концерна «Белнефтехим»

На рисунке 4 можно видеть структуру внутреннего производства химических волокон и нитей в разрезе предприятий-производителей. 


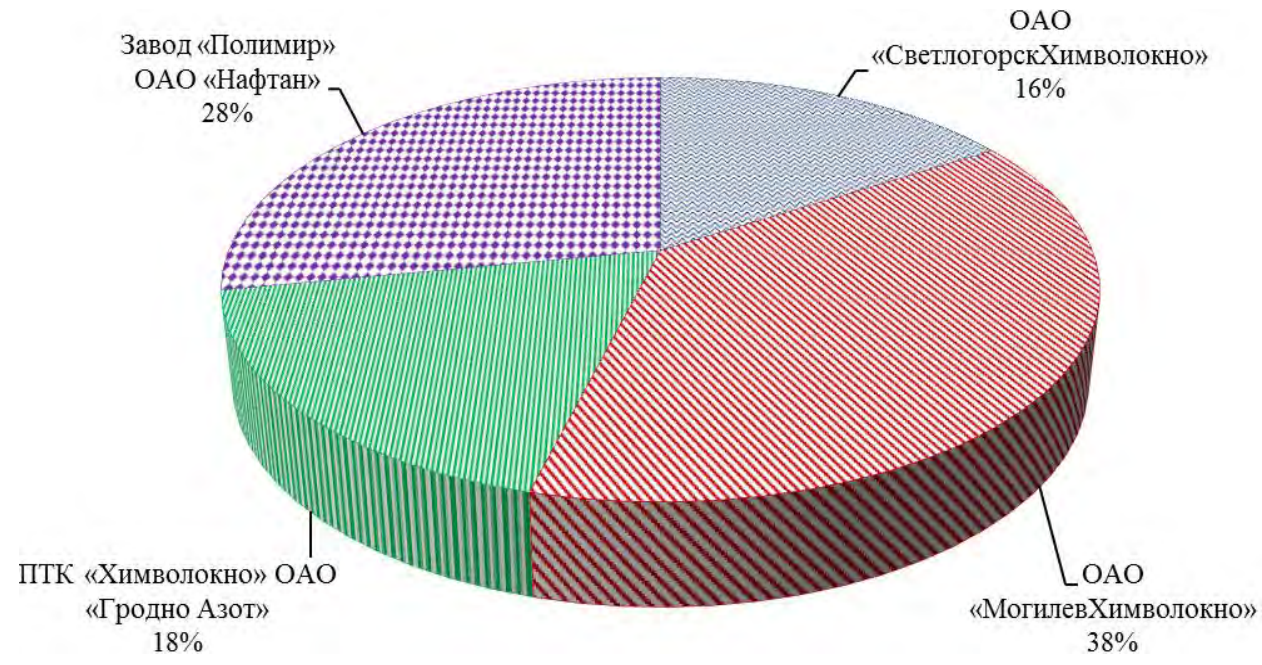

Рисунок 4 - Структура внутреннего производства химических волокон и нитей

Источник: составлено авторами на основе данных концерна «Белнефтехим»

Как видно из рисунка 4 наибольший удельный вес в производстве химических волокон и нитей занимает ОАО «МогилевХимволокно» (38 \% от общего объема производства).

Таким образом, авторами проведен краткий обзор топливной и нефтехимической промышленности Республики Беларусь, выявлены некоторые тенденции развития данной отрасли. Далее проведем анализ исследуемой отрасли на основе системы межотраслевых таблиц «Затраты - Выпуск» Республики Беларусь за 2012 год.

\section{АНАЛИЗ ОТРАСЛИ НА ОСНОВЕ СИСТЕМЫ ТАБЛИЦ «ЗАТРАТЫ - ВЫПУСК»}

Рассматривая нефтехимическую промышленность необходимо разобраться в глубинных процессах ее функционирования, выявить характеристики производства и использования товаров и услуг данной отрасли, а также понять процесс образования, распределения и использования доходов, формирующихся в процессе производства. Для этих целей нами будет использована система межотраслевых таблиц «Затраты-Выпуск» Республики Беларусь за 2012 год, которая является частью СНС [10]. Под нефтехимической промышленностью авторами использованы виды деятельность подсекции DF «Производство кокса, нефтепродуктов и ядерных материалов» и подсекции DG «Химическое производство» согласно Общегосударственному классификатору Республики Беларусь ОКРБ $005-2006$ «Виды экономической деятельности» (ОКЭД).

Итак, авторами был проведен первоначальный экспресс-анализ топливной и нефтехимической промышленности Республики Беларусь в сравнении с показателями в целом по экономике. На рисунке 5 представлено формирование ресурсов по экономике Беларуси, а также в отраслевом разрезе.

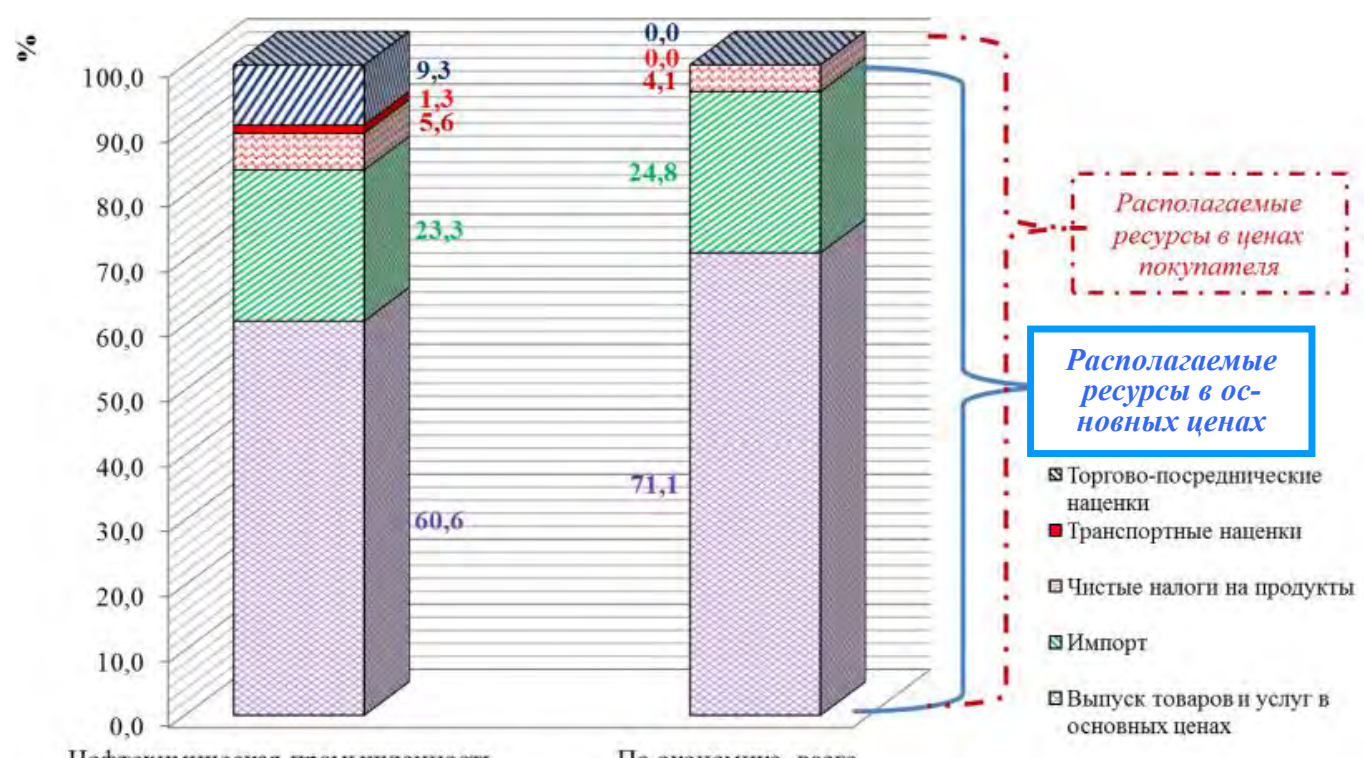

Нефтехимическая промышленность По экономнке, всего

Рисунок 5 - Структура формирования ресурсов Республики Беларусь за 2012 г.

Источник: расчеты авторов на основе системы межотраслевых таблиц «Затраты - Выпуск» Республики Беларусь за 2012 г.

Анализируя рисунок 5, можно заметить, какая часть ресурсов сформирована за счет внутреннего производства, 
а какая за счет импорта и наценок. Так в целом по экономике более $60 \%$ ресурсов сформировано за счет собственного производства, около $23 \%$ приходится на импорт, а оставшаяся часть $17 \%$ на наценки (транспортные, торговые, чистые налоги). По нефтехимии удельный вес импорта выше, чем в среднем по экономике (около 40\% с учетом наценок), что вызвано значительной зависимостью нефтехимии от импортных ресурсов (на 99 \% от Российской Федерации за счет поставок нефти и нефтепродуктов). 2012 год.

На рисунке 6 представлена информация об использовании ресурсов по нефтехимии Республики Беларусь за

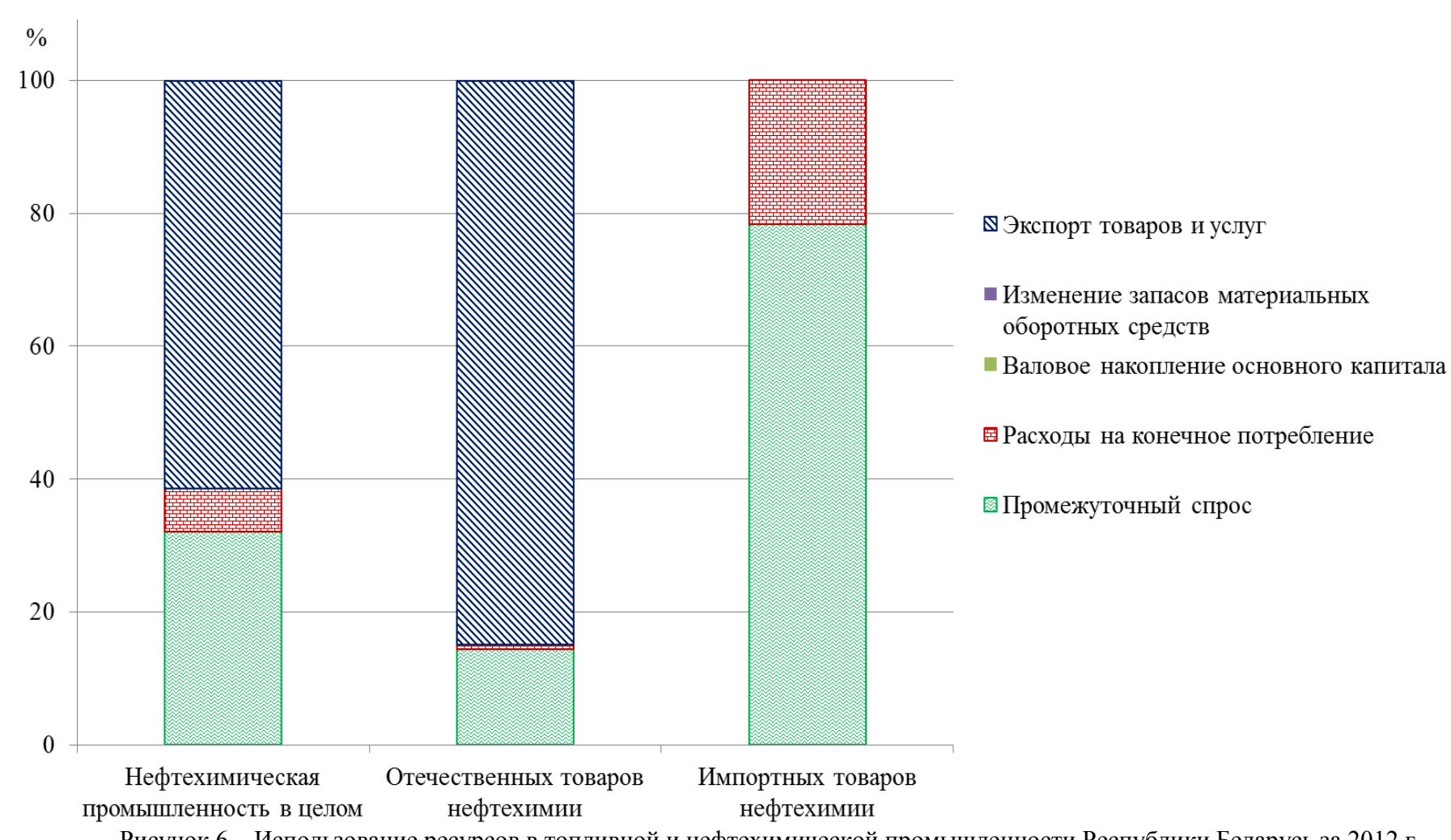

Рисунок 6 - Использование ресурсов в топливной и нефтехимической промышленности Республики Беларусь за 2012 г.

Источник: расчеты авторов на основе системы межотраслевых таблиц «Затраты - Выпуск» Республики Беларусь за 2012 г.

Рисунок 6 характеризует использование товаров и услуг на удовлетворение промежуточного и конечного (конечного потребления, валового накопления и экспорта) спроса. Кроме того, можно проследить поэлементную структуру промежуточного потребления и компоненты добавленной стоимости по нефтехимии. Анализируя, представленные данные, можно отметить, что большая часть импортных продуктов нефтехимии удовлетворяют промежуточный спрос отечественных производителей (около 80 \% всех импортных товаров) и лишь малая часть идет на конечное потребление (около 20 \%). Что касается отечественных товаров, то большая часть (около 85 \%) идет на экспорт. Однако здесь необходимо понимать, что значительная часть данного экспорта сформирована за счет импортных ресурсов. Рассматривая общую структуру, также необходимо отметить, что доля экспорта в использовании ресурсов нефтехимии занимает более 60 \%, что характеризует данную отрасль не только как импортозависимую, но и экспортоориентированную.

Также важным экономическим аспектом является распределение промежуточного спроса и потребления в исследуемой отрасли. Структура промежуточного спроса и потребления в топливной и нефтехимической промышленности в разрезе видов экономической деятельности представлена на рисунке 7.

На рисунке 7 структура промежуточного потребления демонстрирует взаимосвязи топливной и нефтехимической промышленности с другими отраслями национальной экономики. Промежуточные потребление показывает продукты каких отраслей закупаются топливной и нефтехимической промышленностью в качестве промежуточных, т.е. продукты каких отраслей используются для производства продуктов нефтехимии и в каких пропорциях. Исходя из этого несложно заметить, что наибольший удельный вес в нефтехимии занимают промежуточные продукты добыча топливно-энергетических полезных ископаемых (46,9%), нефтепродукты (14,1 \%), продукты химии (12,4 \%), т.е. можно с большой долей уверенности утверждать, что основной объем производства в топливной и нефтехимической промышленности обеспечен продуктами собственного производства, а также топливно-энергетическими полезными ископаемых, на чем основаны ключевые процессы нефтепереработки. 


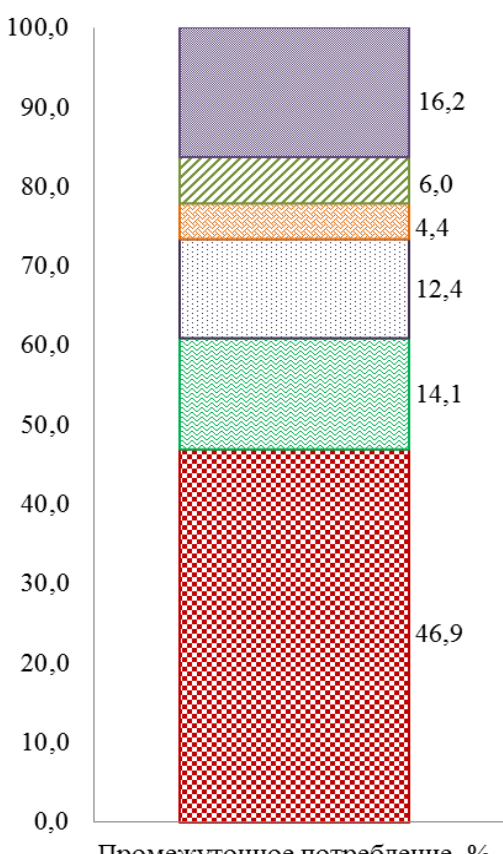

Промежуточное потребление, \%

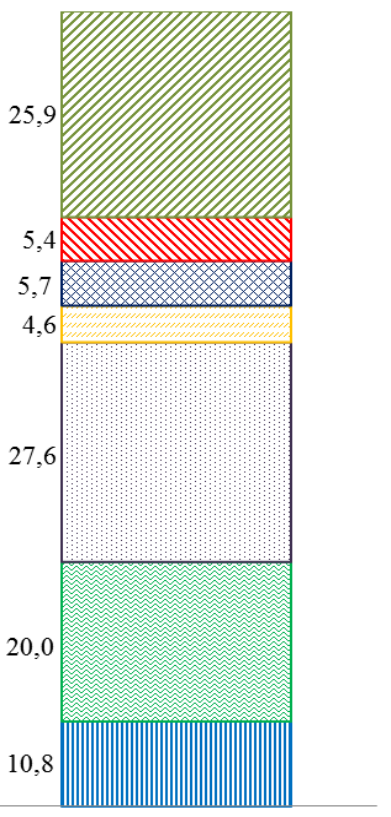

ш Сельское хозяйство, охота и предоставление услуг в этих областях

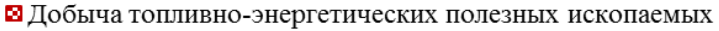

图 Производство кокса, нефтепродуктов и ядерных материалов

๑имическое производство

$\square$ Производство резиновых и пластмассовых изделий

园Производство и распределение электроэнергии, газа и воды

凶Строительство

\ Транспорт и связь

ఐПрочие отрасли

$\square$ Наценки, входящие в промежутоное потребление

Рисунок 7 - Структура промежуточного спроса и промежуточного потребления нефтехимической промышленности в разрезе видов деятельности Республики Беларусь за 2012 г.

Источник: расчеты авторов на основе системы межотраслевых таблиц «Затраты - Выпуск» Республики Беларусь за 2012 г.

Вторая часть диаграммы показывает структуру промежуточного спроса продуктов нефтехимии, т.е. распределение продуктов, произведенных в топливной и нефтехимической промышленности по отраслям экономики в качестве промежуточного потребления. Как уже отмечалось, нефтехимия характеризуется большой долей самообеспеченности продуктами промежуточного потребления, что подтверждено на рисунке 2 (20,0 \% всех нефтепродуктов и 27,6 \% продуктов нефтехимии идут на промежуточное потребление в топливную и нефтехимическую промышленость). Также следует отметить существенную ресурсную зависимость сельского хозяйства (10,8 \% всей продукции нефтехимии), строительства $(5,7 \%)$, транспорта и связи $(5,4 \%)$ от исследуемой отрасли [11].

Так же, как уже было описано ранее, в топливной и нефтехимической промышленности формируется значительная часть валовой добавленной стоимости страны (около 8,8 \% по данным 2012 года). На рисунке 8 представим структуру ВДС Республики Беларусь за 2012 год, в том числе по нефтехимии, в разрезе экономических элементов.

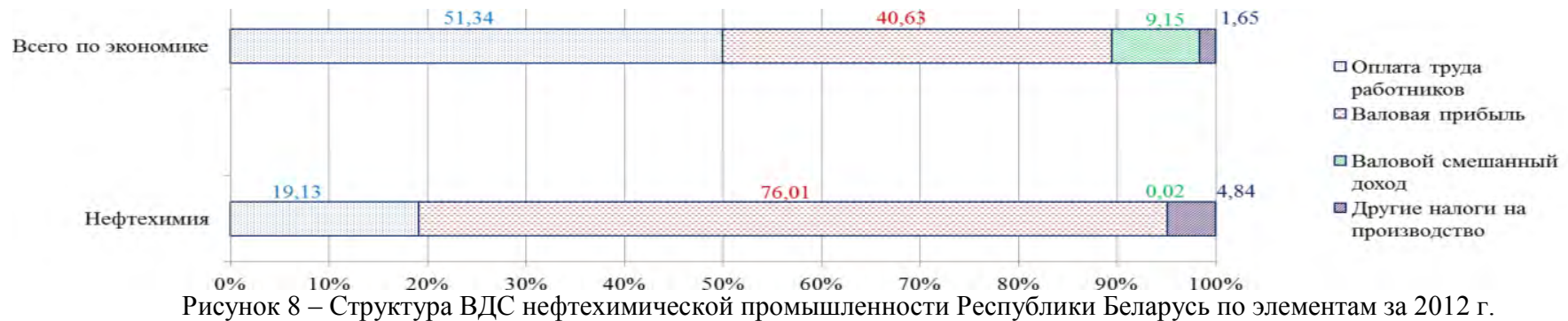

Источник: расчеты авторов на основе системы межотраслевых таблиц «Затраты - Выпуск» Республики Беларусь за 2012 г.

На основании расчетов, представленных на рисунке 8, авторами произведен расчет по распределению ВДС по основным секторам экономики. Расчет произведен как по экономике в целом, так по нефтехимии.

Оплата труда работников и валовой смешанный доход были отнесены к доходам домашних хозяйств, а остальные доходы (валовая прибыль, другие налоги на производство, косвенно измеряемые услуги финансового посредничества) - условно к доходам государства и прочих секторов (рис. 9).

Аналитические данные показывают, что доля дохода, получаемого государством от нефтехимической промышленности, значительно превышает долю дохода, получаемого по экономике в целом (80,85 \% против 42,28 \%).

В заключении анализа, авторами значительное внимание уделено вкладу топливной и нефтехимической промышленности во внешнеэкономическую деятельность страны. Для более глубокого анализа была применена авторская методика, описанная в методологической части данного исследования. Все расчеты представлены в таблице 2. 


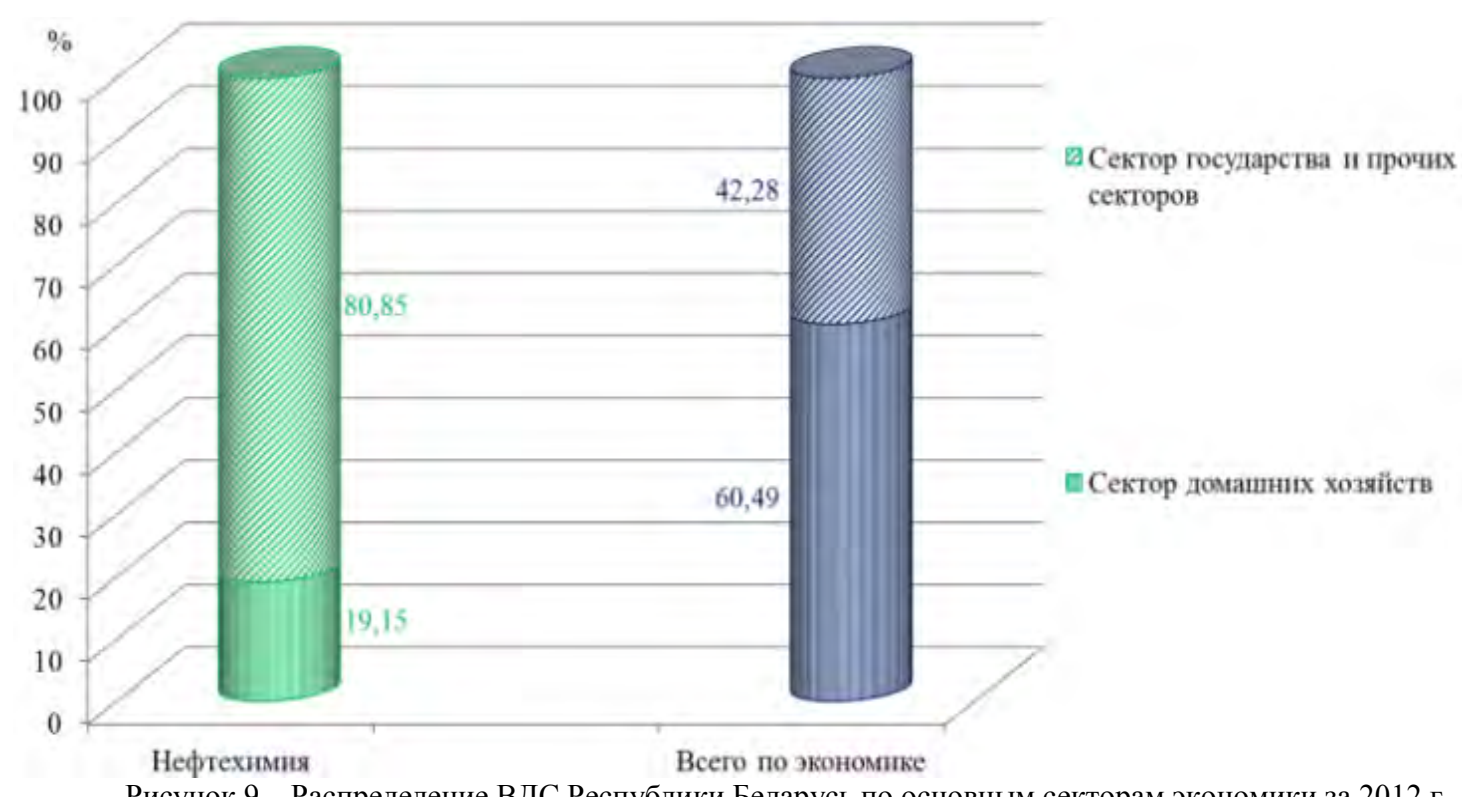

Источник: расчеты авторов на основе системы межотраслевых таблиц «Затраты - Выпуск» Республики Беларусь за 2012 г.

Таблица 2 - Расчетная таблица по экспорту нефтехимической продукции и в целом по экономике Республики Беларусь за 2012 г.

\begin{tabular}{|c|c|c|c|}
\hline Показатель & Формула расчета & $\begin{array}{l}\text { Нефтехимическая } \\
\text { промышленность }\end{array}$ & $\begin{array}{c}\text { По экономике, } \\
\text { всего }\end{array}$ \\
\hline 1. ВДС*, трлн. руб. & - & 40,6 & 463,0 \\
\hline $\begin{array}{l}\text { 2. Выпуск товаров и услуг в основных ценах (В) *, } \\
\text { трлн. руб. }\end{array}$ & - & 199,6 & 1166,6 \\
\hline 3. Промежуточное потребление (ПП)*, трлн. руб. & В - ВДС & 159,0 & 703,6 \\
\hline 4. Доля местных ресурсов (ДМР) & $\begin{array}{l}\text { ПП отечественных } \\
\text { товаров / общее ПП }\end{array}$ & $0,21(21 \%)$ & $0,57(57,0 \%)$ \\
\hline 5. Импортное промежуточные потребление, трлн. руб. & $\Pi \Pi \times(1-Д М Р)$ & 125,3 & 302,7 \\
\hline 6. Местный промежуточный спрос (МПП), трлн. руб. & ПП × ДМР & 33,6 & 400,9 \\
\hline 7. Экспорт без наценок (Э)*, трлн. руб. & - & 169,4 & 365,2 \\
\hline 8. Экспорт с наценками (ЭН)*, трлн. руб. & - & 195,8 & 431,4 \\
\hline 9. Доля ДС экспорта $\left(\mathrm{d}_{\text {Дсэ) }}\right)$ & ВДС/В & $0,20(20 \%)$ & $0,397(40 \%)$ \\
\hline 10. ДС экспорта (ДСЭ), трлн. руб. & $\mathrm{d}_{\text {дсэ }} \times Э_{\mathrm{H}}$ & 39,8 & 123,7 \\
\hline 11. Доля местных ресурсов в выпуске $\left(\mathrm{d}_{\mathrm{MP}}\right)$ & МПП/В & $0,17(17 \%)$ & $0,34(34 \%)$ \\
\hline 12. Экспорт за счет местных ресурсов (ЭМР), трлн. руб. & $\mathrm{d}_{\mathrm{MP}} \times Э_{\mathrm{H}}$ & 33,0 & 124,5 \\
\hline 13. Наценки в экспорте $(\mathrm{H})^{*}$, трлн. руб. & & 26,4 & 66,2 \\
\hline 14. Экспорт за счет импортных ресурсов, трлн. руб. & $Э_{\mathrm{H}}-$ ЭМР - ДСЭ-H & 96,6 & 117,0 \\
\hline
\end{tabular}

Источник: расчеты авторов на основе системы межотраслевых таблиц «Затраты - Выпуск» Республики Беларусь за 2012 г.

В приведенной таблице отображены расчеты полной добавленной стоимости в абсолютном и относительном выражении по методике учета международной торговли ОЭСР-ВТО по Республике Беларусь, а также нефтехимии, в целях сопоставления показателей торговли Беларуси с международными данными. Исходными данными для проведения расчетов послужила система таблиц «Затраты-Выпуск» Республики Беларусь за 2012 год.

Зная суммы добавленной стоимости и местных ресурсов в экспорте, а также суммы наценок (транспортные, торговые наценки, чистые налоги) найдена сумма экспорта за счет местных и импортных ресурсов с учетом наценок (табл. 2, пп. 12, 14), а также величина добавленной стоимости в экспорте Республики Беларусь (табл. 2, п. 10).

Из расчетной таблицы видно, что почти половина экспорта продуктов нефтехимии сформирована за счет импортных ресурсов (49,3\%), что подтверждает высокую импортозависимость исследуемой отрасли. Сопоставляя полученные данные с географией импорта, заметим, что импортозависимость белорусской нефтехимии в большей степени обусловлена Российской Федерацией, как основным поставщиком сырой нефти и нефтепродуктов $\quad(96,2 \%$ всего импорта по данным за 2012 г.) [12]. 


\section{ВЫВОДЫ}

Таким образом, проанализированы основные тенденции и выявлены перспективы развития топливной и нефтехимической промышленности Республики Беларусь, а также определено существенное влияние данной отрасли на экономику страны.

Авторами проведен детальный обзор исследуемой отрасли, а также ее глубокий анализ на основе системы межотраслевых таблиц «Затраты - Выпуск» Республики Беларусь за 2012 год. В качестве методологической базы была использована авторская методика, в целях расчета величины экспорта в нефтехимической промышленности, сформированной за счет использования импортных ресурсов в качестве продуктов промежуточного потребления. Проведен глубокий анализ внешнеэкономической деятельности, а также выявлены существенные взаимосвязи нефтехимической промышленности с другими отраслями национальной экономики на базе анализа промежуточного потребления и спроса.

Полученные результаты исследования, а также сформулированные выводы могут иметь конкретное практическое применение. На основе анализа выявленные тенденции могут быть учтены при разработке экономической политики государства, а также при формировании Программы развития промышленного комплекса Республики Беларусь и разработки внешнеэкономической политики.

\section{ЛИТЕРАТУРА}

1. Белорусский государственный концерн по нефти и химии [Электронный ресурс] / О концерне. - Режим доступа: http://www.belneftekhim.by/about/. - Дата доступа: 22.06.2015.

2. Готовский, А.В. Вклад экспорта в экономический рост Республики Беларусь / Готовский, А.В., Гуцол, П.Н. // Белор. эконом. журнал. - 2017. - № 2. - С. 4 - 16.

3. ЗАО «Инвестиционная компания «ЮНИТЕР» [Электронный ресурс] / Топливная и нефтехимическая промышленность. $\quad$ - $\quad$ Минск, $2012 . \quad$ - 20 Режим http://www.mzv.cz/file/703106/Palivovy_a_petrochemicky_prumysl_Juniter_pdf. - Дата доступа: 30.09.2014.

4. ПО «Белоруснефть» [Электронный ресурс] / История. Хроника событий. - Режим доступа: http://www.belorusneft.by/sitebeloil/ru/addUp/about/history/. - Дата доступа: 23.06.2015.

5. Белорусский государственный концерн по нефти и химии [Электронный ресурс] / Состоялась прессконференция председателя концерна Игоря Ляшенко «О развитии нефтехимического комплекса Республики Беларусь». - Режим доступа: http://www.belneftekhim.by/press/news/d71409f0fc2bd647.html. - Дата доступа: 06.07.2015.

6. Быков, А. А. О причинах и возможных последствиях снижения мировых цен на нефть / А. А. Быков // Белор. эконом. журнал. - 2014. - № 4. - С. 4 - 16.

7. Белорусский государственный концерн по нефти и химии [Электронный ресурс] / Состоялась прессконференция председателя концерна Игоря Ляшенко «О развитии нефтехимического комплекса Республики Беларусь». - Режим доступа: http://www.belneftekhim.by/press/news/d71409f0fc2bd647.html. - Дата доступа: 06.07.2015.

8. Белорусский государственный концерн по нефти и химии [Электронный ресурс] / Состоялась прессконференция председателя концерна Игоря Ляшенко «О развитии нефтехимического комплекса Республики Беларусь». - Режим доступа: http://www.belneftekhim.by/press/news/d71409f0fc2bd647.html. - Дата доступа: 06.07.2015.

9. ОАО «Нафтан» завод «Полимир» [Электронный ресурс] / Общая информация. - Режим доступа: http://www.polymir.by/general/. - Дата доступа: 06.07.2015.

10. Система таблиц «Затраты-Выпуск» Республики Беларусь за 2012 год (стат. бюлл.) / Национальный статистический комитет Республики Беларусь. - Минск, 2014. - 106 с.

11. Быков, А.А. Макроструктура национальной экономики и энергетические риски / А.А. Быков // Белор. эконом. журнал. - 2012. - № 2. - С. $48-60$.

12. Быков, А.А. Оценка условий коммерческой эффективности и потенциала производства биодизельного топлива в Беларуси / А.А. Быков, С.В. Сакун // Белор. эконом. журнал. - 2013. - № 3. - С. 48 -57.

Статья поступила в редакиию 8 июля 2015 года. 